\title{
De verschuivende functies van de Awb
}

\author{
B.J. Schueler
}

\section{Inleiding}

De Nederlandse bestuursrechtelijke wetgeving is verspreid over één algemene wet voor het hele bestuursrecht, de Algemene wet bestuursrecht (Awb), en vele bijzondere wetten voor de deelterreinen. Sommige deelterreinen hebben ook een eigen algemene wet over een aantal onderwerpen, zoals besluitvorming, rechtsbescherming en handhaving, die van belang zijn bij de uitvoering van andere, meer inhoudelijke wetten op dat deelterrein. Een voorbeeld daarvan is de Algemene wet inzake rijksbelastingen (AWR). Een andere variant is die van de Wet algemene bepalingen omgevingsrecht (Wabo) en de toekomstige Omgevingswet. Deze algemene omgevingsrechtelijke wetten regelen de hoofdlijnen en structuren van een deelterrein en bieden tevens de wettelijke basis voor lagere regelgeving (op zowel rijksniveau als decentraal niveau). In die variant gaat het vooral om integratie van samenhangende wettelijke complexen en veel minder, zoals bij de Awb, om een algemene wet die wordt toegepast bij de uitvoering van andere wetten.

Wil de wetgever een bepaald onderwerp regelen, dan staat hij voor de keuze: doet hij dat in de Awb, in een bijzondere wet of in een algemene wet voor een deelterrein? Aan de Awb en aan artikel 107 van de Grondwet (Gw) ligt de gedachte ten grondslag dat het zin heeft om algemene regels van bestuursrecht in de wet vast te leggen. Maar deze gedachte is niet zover doorgevoerd dat de wetgever de voorkeur moet geven aan algemene regels boven bijzondere. Er zijn onderwerpen die op verschillende deelterreinen voorkomen en zich vanuit de gedachte van harmonisatie lenen voor een regeling in de Awb, maar waar ook kanten aan zitten die reden kunnen zijn om een specifieke regeling voor een deelterrein te maken.

Wat zijn de belangrijkste redenen om algemene regels op te nemen in de Awb in plaats van een regeling te maken voor een deelterrein? In deze bijdrage worden de meest voor de hand liggende redenen besproken vanuit vijf invalshoeken: rechtseenheid, kenbaarheid, voorspelbaarheid, efficiëntie in de wetgeving en borging van rechtsstatelijkheid.

Deze bespreking leidt tot de bevinding dat elk van deze invalshoeken belangrijk is, maar dat in het huidige tijdsgewricht, naast de efficiency in de wetgeving, vooral het belang van de borging van rechtsstatelijkheid groot is. Dat werpt een nieuw licht op de functie van de Awb. Daarop is in 2014, bij de viering van het 75-jarig bestaan van de VAR, de aandacht gevestigd door Michiel Scheltema, wiens werk nauw is verweven met de totstandkoming van de Awb en de verdere ontwikkeling van en gedachtevorming over die wet sinds deze in 1994 in werking is getreden. Hij zei het wel eens te betreuren 
'dat de memorie van toelichting de doelstellingen van de Algemene wet bestuursrecht wat beperkt heeft omschreven. ${ }^{1}$ Velen zullen die kennen: het gaat over codificatie en het brengen van eenheid en consistentie in het bestuursrecht. Groot en meeslepend zijn die doelstellingen niet te noemen, zeker niet voor anderen dan juristen. Het zou beter zijn geweest wanneer de verbinding met de waarden van de rechtsstaat meer expliciet was gelegd.'

Hij stelde een actuele herformulering van het doel van de Awb voor: 'het bieden van een eigentijds bestuursrechtelijk kader voor effectief bestuur op basis van de waarden van de rechtsstaat'.

In hun bijdrage in deze aflevering van RegelMaat hebben Stip en Zijlstra drie hoofdcategorieën van rechtseenheid onderscheiden, waarvan er een is: 'de rechtseenheid die ziet op het voorkómen van verschillende uitleg en toepassing van dezelfde rechtsnormen binnen een rechtsorde'. ${ }^{3}$ In paragraaf 2 zal ik ingaan op de vraag hoe de Awb moet worden geplaatst in het kader van dit aspect van rechtseenheid. Daaruit zal naar voren komen dat het zinvol is een onderscheid te maken tussen eenheid in uitleg van de Awb op abstract niveau en toepassing ervan in de context van een bepaald deelterrein van het bestuursrecht.

Vanuit de invalshoek van kenbaarheid en toegankelijkheid wordt in paragraaf 3 betoogd dat de Awb daar een bijdrage aan levert, maar dat deze wet een gelaagdheid creëert die de rechtstoepassing kan compliceren. Kenbaarheid en toegankelijkheid kunnen vaak beter op een deelterrein worden bevorderd door middel van integratie van wetgeving.

Het opstellen van uniforme regels wordt ook ingegeven door de gedachte dat dit de rechtstoepassing beter voorspelbaar maakt. Ten dele is die gedachte juist, maar harmonisatie en integratie gaan gepaard met abstracte normen en met afwegingsen afwijkingsruimte. Daardoor wordt het vaak juist moeilijk de uitkomst van besluitvorming of rechtspraak te voorspellen.

Stip en Zijlstra noemen ook de efficiency als een argument voor het streven naar rechtseenheid: de wetgever hoeft niet steeds 'het wiel uit te vinden'. ${ }^{4}$ In paragraaf 5 zal ik het belang van de Awb voor de efficiency in het wetgevingsproces onderstrepen, in het bijzonder in het kader van grote wetgevingsprojecten.

Ten slotte wordt in paragraaf 6 de verwachting uitgesproken dat in het huidige tijdsgewricht het belang van de Awb voor de borging van rechtsstatelijkheid groot zal blijken te zijn.

1 E.J. Daalder \& G.R.J. de Groot, De parlementaire geschiedenis van de Algemene wet bestuursrecht. Eerste tranche (hierna: PG Awb I), Alphen aan den Rijn: Samsom H.D. Tjeenk Willink 1993, p. 18-23.

2 M. Scheltema, 'Rechtseenheid of rechtsstaat als doelstelling van de Awb?', NJB 2015/814.

3 M.J.C. Stip \& S.E. Zijlstra, 'Rechtseenheid: concepten, motieven, actoren en instrumenten', RegelMaat 2015, afl. 6, par. 2.

$4 \quad$ Stip \& Zijlstra 2015, par. 4.2. 


\section{Rechtseenheid}

Rechtseenheid dient een aantal doelen, waarvan zekerheid en gelijkheid de belangrijkste zijn. Onnodige verschillen tussen regels op verschillende deelterreinen creëren onzekerheid bij de toepassing van het bestuursrecht en bij het voorspellen van de uitkomst van besluitvorming en rechtspraak. En onnodige verschillen kunnen ook tot gevolg hebben dat gevallen ongelijk worden behandeld zonder dat dit wordt gerechtvaardigd door relevante verschillen in omstandigheden. Rechtseenheid kan bijdragen aan de effectiviteit van het recht: als mensen de zekerheid hebben dat hun eigen geval in het licht van de wet gelijk zal worden beoordeeld als soortgelijke andere gevallen, zullen zij eerder geneigd zijn zich naar die wet te gedragen. Rechtseenheid helpt zo ook te voorkomen dat individuele gevallen onnodig vaak aan een rechter moeten worden voorgelegd om erachter te komen wat de wet per geval betekent. Een algemene wet als de Awb kan bijdragen aan het verbeteren van de rechtseenheid omdat zij onnodige verschillen in de wet helpt voorkomen en wegnemen.

Het is begrijpelijk dat algemene regels, eenmaal tot stand gebracht, de verwachting wekken dat zij ook uniform zullen worden uitgelegd en toegepast. Daarmee stuiten we op een probleem dat in de loop van de afgelopen twee decennia aan het licht is gekomen. ${ }^{5}$ Wij moeten hier verschil maken tussen uitleg in abstracto en de toepassing op een bepaald deelterrein.

Verscheidenheid bij de toepassing van de Awb is geen probleem, integendeel. De Awb moet worden toegepast op zeer uiteenlopende terreinen als belastingen, vergunningen, bestemmingsplannen, subsidies, sociale zekerheid, zorg en welzijn, onderwijs, vreemdelingenrecht en ambtenarenrecht. Het is ondenkbaar dat regels op al die terreinen uniform zouden moeten worden toegepast. De voorbereiding van een bestemmingsplan is slechts op een zeer abstract niveau te vergelijken met de voorbereiding van een besluit tot intrekking van kinderopvangtoeslag. Ook de toetsing van deze besluiten aan een norm als de evenredigheid (art. 3:4 lid 2 Awb) vertoont slechts op het abstractste niveau gelijkenis.

De open normen van de Awb zeggen niet welke concrete belangen en feiten bij het voorbereiden van besluiten en de toetsing daarvan moeten worden betrokken. Die inhoudelijke aspecten van het bestuursrecht worden aangereikt of opgelegd door middel van bijzondere wetten. Dat betekent nog niet dat de normen van de Awb niet uniform worden uitgelegd op abstract niveau. De evenredigheidsnorm van artikel 3:4 lid 2 Awb kan geabstraheerd van de context waarin die wordt toegepast uniform worden uitgelegd en vervolgens leiden tot sterk uiteenlopende toepassingen. Doorgaans wordt de evenredigheidsnorm zo uitgelegd dat een besluit geschikt moet zijn voor het beoogde doel, terwijl dat doel niet met een minder ingrijpend middel kan worden bereikt en er een redelijke verhouding is tussen het doel en de nadelige gevolgen. In abstracto kan men die uitleg overal 
gebruiken. ${ }^{6}$ Een abstracte uitleg van de norm is mogelijk zonder de in concreto betrokken feiten en belangen erbij te betrekken. Bij de toepassing worden die feiten en belangen er wel bij betrokken en dragen zij eraan bij dat de norm sterk uiteenlopende resultaten kan hebben. Dat gebeurt zowel in de fase van de bestuurlijke besluitvorming als in die van de rechterlijke toetsing. Dat kan bijvoorbeeld tot gevolg hebben dat de toetsing of er een redelijke verhouding is tussen het doel en de nadelige gevolgen op sommige terreinen terughoudender is dan op andere. In de ruimtelijke ordening, waar veel bestuurlijke afwegingsruimte bestaat en nodig is, is die toetsing terughoudender dan bij de beoordeling van opgelegde boetes.

Bij de toepassing van een open norm uit de Awb wordt in zekere zin ook een nadere uitleg aan de norm gegeven binnen een bepaalde context. Deze nadere uitleg kan verschillen van die op andere deelterreinen. Toch is het zinvol dat op het abstracte niveau van de Awb de algemene norm geldt en ook op dat abstracte niveau wordt uitgelegd, ook al wordt deze verschillend toegepast op deelterreinen. De abstracte norm voorkomt dat op een deelterrein de rechtstoepassing te ver verwijderd raakt van (in dit voorbeeld) de evenredigheidsnorm.

Uit een oogpunt van rechtseenheid is het moeilijker te aanvaarden als regels van de Awb door verschillende rechters verschillend worden begrepen op het abstracte niveau. Dan wordt de wetgever verschillend 'verstaan'. Dat komt wel eens voor. ${ }^{7}$ Doorgaans wordt het interpretatieverschil door middel van afstemming van jurisprudentie of overleg tussen de hoogste bestuursrechters rechtgetrokken. Dan wordt een uniforme uitleg gevonden. ${ }^{8}$

In situaties waarin gesproken wordt over verschillen die omwille van de rechtseenheid zouden moeten worden weggenomen, gaat het vaak niet om verschillen in abstracte uitleg maar om verschillen in toepassing van Awb-regels. Verscheidenheid hoeft in deze gevallen niet problematisch te zijn. Vanuit een oogpunt van goede rechtsbedeling zijn verschillen in toepassing vaak zelfs wenselijk. Ik geef daarvan twee voorbeelden.

De belastingrechter gaat vanouds met de beoordeling van ontvankelijkheidskwesties anders om dan de andere bestuursrechters. Als de belanghebbende enig feit

6 A. de Moor-van Vugt, Maten en gewichten. Het evenredigheidsbeginsel in Europees perspectief, Zwolle: W.E.J. Tjeenk Willink 1994; A.J. Nieuwenhuis, B.J. Schueler \& C.M. Zoethout, Proportionaliteit in het publiekrecht, Deventer: Kluwer 2005; E.H.M. Hirsch Ballin, 'Dynamiek in de bestuursrechtspraak', in: Rechtsontwikkeling door de bestuursrechter (VAR-reeks 154), Den Haag: Boom Juridische uitgevers 2015, p. 7-58.

7 R. Ortlep, 'Optimaliseren rechtseenheid tussen de hoogste bestuursrechters', in: Rechtsontwikkeling door de bestuursrechter (VAR-reeks 154), Den Haag: Boom Juridische uitgevers 2015, p. 59 e.v.

8 A.J.C. de Moor-van Vugt, 'Rechtseenheid als kwaliteitsvraagstuk', in: T. Barkhuysen e.a. (red.), Bestuursrecht harmoniseren: 15 jaar Awb, Den Haag: Boom Juridische uitgevers 2010, p. 299-317; M.W.C. Feteris, 15 jaar Awb en belastingrecht, in: T. Barkhuysen e.a. (red.), Bestuursrecht harmoniseren: 15 jaar Awb, Den Haag: Boom Juridische uitgevers 2010, p. 359-373; B.J. van Ettekoven, 'Rechtseenheid vanuit het perspectief van de rechtbanken', in: T. Barkhuysen e.a. (red.), Bestuursrecht harmoniseren: 15 jaar Awb, Den Haag: Boom Juridische uitgevers 2010, p. 281-297; B.J. van Ettekoven, 'One peak or twin peaks? Het regeerakkoord en de toekomst van de bestuursrechtspraak’, NJB 2013, p. 596-603. 
had gesteld over de tijdige indiening van zijn beroepschrift en dit tussen partijen niet in geschil was, ging de belastingrechter daarvan uit. ${ }^{9}$ Hij verklaarde dus niet ambtshalve het beroepschrift niet-ontvankelijk. De andere bestuursrechters onderzoeken ambtshalve de feiten die nodig zijn voor de ambtshalve beoordeling van kwesties van openbare orde, ook als die feiten tussen partijen niet in geschil zijn. Het verschil tussen deze benaderingen stuitte op kritiek, onder andere bij de rechtbanken. ${ }^{10}$ In 2011 is de Hoge Raad opgeschoven in de richting van de andere bestuursrechters. De belastingrechter is nu gehouden ambtshalve onderzoek te doen naar de aannemelijkheid van feiten die door een partij in verband met de ontvankelijkheid worden aangevoerd, ook indien die gestelde feiten door de wederpartij worden erkend of niet worden betwist. ${ }^{11}$ De wens van rechtseenheid is vervuld. Maar welk belang is daarmee gediend? In belastingzaken wordt niemand benadeeld doordat het verwerende bestuursorgaan ervan afziet een beroep te doen op de niet-ontvankelijkheid wegens termijnoverschrijding. Op andere terreinen van het bestuursrecht bestaat het gevaar van benadeling wel, met name als de belangen van derden in het geding zijn. Daarom is het niet alleen begrijpelijk, maar ook verantwoord dat hier verschillend mee omgegaan werd. Dit voorbeeld laat zien dat soms de rechtseenheid een doel op zich dreigt te worden, waarvoor het belang van een goede rechtstoepassing moet wijken.

De gedachte dat het streven naar rechtsgelijkheid meebrengt dat de regels van de Awb gelijk moeten worden toegepast, heeft dus dubieuze kanten. Er zijn verschillen die juist goed te verdedigen zijn. Alleen waar die rechtvaardiging niet mogelijk is, is het wenselijk om ongerijmdheden weg te nemen. ${ }^{12}$ Het ging in dit voorbeeld niet om een verschil in uitleg van een wettelijke norm uit de Awb, want de Awb bevat geen bepaling over de vraag of een beroep ambtshalve niet-ontvankelijk moet worden verklaard als het te laat is ingediend. Een toepassingspraktijk waarin de rechter ervan uitgaat dat het rechtsmiddel tijdig is ingediend indien partijen daar zelf van uitgaan, is niet in strijd met enige Awb-bepaling.

$\mathrm{Nu}$ het tweede voorbeeld. De Awb regelt niet wat het object van geding in hoger beroep is. ${ }^{13}$ Is dat alleen de uitspraak van de rechtbank of ook het in eerste aanleg bestreden besluit? De Centrale Raad van Beroep en de Afdeling bestuursrecht-

$9 \quad$ HR 1 april 2005, AB 2005/246 m.nt. Widdershoven.

10 R.J.G.M. Widdershoven e.a., Evaluatie belastingrechtspraak in twee instanties. Eindrapport fase II (2008) en fase III (2010), Den Haag: Raad voor de rechtspraak, p. 23-24 en 119-120.

11 HR 13 mei 2011, AB 2011/158 m.nt. Widdershoven, JB 2011/146 m.nt. Bok, NTFR 2011/1148 m.nt. Den Ouden. In HR 14 september 2012, BNB 2012/277 overwoog de Hoge Raad dat het hof gehouden was de voor de ontvankelijkheid van het beroep bij de rechtbank relevante feiten te onderzoeken en vast te stellen.

12 Ortlep 2015, p. 101 e.v. en ook R. Ortlep, "Het "feestje" van de rechtseenheid bij de hoogste bestuursrechters', NJB 2013, afl. 41, p. 2874.

13 J.G. Treffers, 'Rechtseenheid in het bestuursrechtelijk appel. Of: hoe ver het moet en hoe ver het kan', in: R.J.N. Schlössels, A.J. Bok, A.G.A. Nijmeijer \& L.J.M. Timmermans (red.), In eenheid. Over rechtseenheid en uniforme rechtstoepassing in het bestuursrecht, Den Haag: Sdu Uitgevers 2007, p. 239-250; A.M.M.M. Bots, 'Het trechtermodel in het licht van het rechtseenheidsvraagstuk', in: R.J.N. Schlössels, A.J. Bok, A.G.A. Nijmeijer \& L.J.M. Timmermans (red.), In eenheid. Over rechtseenheid en uniforme rechtstoepassing in het bestuursrecht, Den Haag: Sdu Uitgevers 2007, p. 251-272. 
spraak gaan daar verschillend mee om. De Awb laat alle ruimte voor dit verschil, want zij bepaalt niets over het object van geding in hoger beroep. Het gaat hier dus ook niet om verschil in uitleg op abstract niveau, maar om verschillende toepassingen van dezelfde wet. En die souplesse moet positief worden gewaardeerd. ${ }^{14}$ Als er goede redenen kunnen worden gegeven voor de verschillen in de keuzes van wat wordt gezien als het object van geding in hoger beroep, is er geen strijd met rechtsgelijkheid. Als de verschillen in jurisprudentie duidelijk zijn, is er ook niets mis met de rechtszekerheid. En goede redenen zijn er: in de sociale zekerheid gaat de rechter anders om met de herkansingsfunctie van het hoger beroep dan de Afdeling in het ordenend recht. Want in het ordenend recht hebben (vaak grote groepen ) derden belang bij een definitieve uitkomst. Daarom moet de ruimte voor partijen om het geschil halverwege uit te breiden, worden beperkt. Door zo'n uitbreiding van het geschil kunnen derden immers worden benadeeld.

Een andere vraag is of een rechterlijk college dat zowel met tweepartijengeschillen te maken heeft als met meerpartijengeschillen en bovendien oordeelt over besluiten waar, ongeacht het aantal partijen, derden van afhankelijk zijn (zoals in het omgevingsrecht), er verstandig aan zou doen om per geval te bekijken welke ruimte partijen in hoger beroep krijgen. Zo'n onvoorspelbare handelwijze zou de processuele rechtszekerheid bedreigen, omdat het soort procesgang bij een college dan van geval tot geval zou kunnen verschillen. Bovendien is het niet mogelijk om strikte grenzen te trekken tussen zuivere tweepartijengeschillen en geschillen waarbij de belangen van anderen (als partij, als belanghebbende of anderszins) zijn betrokken. Een rechterlijk college moet zo veel mogelijk naar consequente procesvoering streven. ${ }^{15}$ Dat is een reden om de grenzen tussen verschillende processtijlen zo te trekken dat er geen onzekerheid over bestaat. Het deelterrein van de sociale zekerheid is bijvoorbeeld goed te begrenzen en dat van het belastingrecht ook. Het is dan aan de wetgever ervoor te zorgen dat een deelterrein in hoger beroep terechtkomt bij de rechter die over dat deelterrein gaat en niet deels bij andere rechters. Maar afgezien van eventuele competentiecorrecties hoeft het procesrecht van de Awb er niet voor te worden veranderd.

De voorbeelden laten zien dat de Awb op uiteenlopende terreinen soms verschillend wordt toegepast, dat daar goede redenen voor kunnen zijn en dat dit niet hoeft te strijden met rechtsgelijkheid en rechtseenheid.

Wat betekenen deze Awb-ervaringen voor de wetgever? Ik meen dat eruit kan worden geleerd dat het goed zou zijn als de Awb de ruimte voor verschillende toepassingen op uiteenlopende terreinen behoudt. Bij de enkele constatering dat er een verschil bestaat in de toepassing van de Awb is de rechtseenheid op zich onvoldoende reden voor pogingen om te komen tot nieuwe uniforme regels. Pas als de verschillen in toepassing uit een oogpunt van rechtsgelijkheid of rechtszekerheid niet te verantwoorden zijn, is rechtseenheid een goed argument voor harmonisatie.

14 W. Konijnenbelt, 'Bestuursprocesrecht: Jozefs rok?', NTB 2003, p. 1-4.

15 M. Schreuder-Vlasblom, Rechtsbescherming en bestuurlijke voorprocedure, Deventer: Kluwer 2013, p. 1090. 
Van rechtsongelijkheid is bij Awb-regels niet snel sprake. Deze regels kennen bijna nooit materieelrechtelijke aanspraken toe. ${ }^{16}$ En hun abstracte, grotendeels formele karakter brengt mee dat voor verschillende toepassingen op uiteenlopende terreinen vaak wel een rechtvaardiging bestaat.

Dat uiteenlopende toepassingspraktijken zullen leiden tot rechtsonzekerheid is voorstelbaar. Of dat gebeurt, hangt in hoge mate af van de duidelijkheid van de jurisprudentie, waarin moet worden aangegeven op welke terreinen verschillen bestaan en waarom die worden gemaakt. Als de onzekerheid blijft bestaan, kan de wetgever ingrijpen door de Awb aan te scherpen of te verduidelijken. Dat hoeft niet te leiden tot meer rechtseenheid, want er kan juist een goede reden zijn om meer differentiatie aan te brengen in de Awb indien de praktijk die behoefte zichtbaar maakt. ${ }^{17}$

\section{Kenbaarheid en toegankelijkheid}

Een andere invalshoek is die van de kenbaarheid en toegankelijkheid van de bestuursrechtelijke wetgeving. Achter deze twee woorden gaat een hardnekkig probleem schuil. De bestuursrechtelijke wetgeving wordt naar de ervaring van velen steeds complexer en ook minder begrijpelijk. De Awb is van oorsprong vooral bedoeld om dit probleem aan te pakken. Aan de memorie van toelichting bij de eerste tranche van de Awb ontleen ik het volgende citaat:

'Uit het gezichtspunt van alle deelnemers aan het rechtsverkeer - de burger, de wetgever, het bestuur en de rechter - heeft eenheid in de wetgeving het grote belang dat het recht eenvoudiger en daardoor beter toegankelijk wordt. Wetten behoren duidelijk te zijn; wordt aan dat vereiste niet voldaan, dan kan de wetgever moeilijk aanspraak op naleving ervan maken en verschaffen zij niet de rechtszekerheid die van goede wetgeving mag worden verwacht. Aan de kenbaarheid van het recht wordt ernstig afbreuk gedaan wanneer eenzelfde onderwerp op uiteenlopende wijzen in de wetgeving wordt geregeld. Op grond van een aantal overwegingen is een enkele bepaling in een algemene wet uit dit gezichtspunt verre te verkiezen boven een veelheid van onderling weer verschillende regels in bijzondere wetten. ${ }^{18}$

16 Een voorbeeld van een bepaling die dat wel doet, is het toekomstige art. 4:126 Awb over nadeelcompensatie.

17 R.M. van Male, 'Termijnen: het wordt tijd voor differentiatie', NTB 2008, p. 129-130; R.M. van Male, 'Termijnen moeten op de agenda', NTB 2014, p. 83-85; W. Konijnenbelt, 'Eenkleurige belanghebbenden', NTB 1997, afl. 8, p. 320-321; W. Konijnenbelt, 'Prudent wetgeven', NTB 2010, afl. 29, p. 1-4; Konijnenbelt 2003; G.T.J.M. Jurgens, 'Schadevergoeding als pilot voor differentiatie in het bestuursrecht', NTB 2007, p. 257-259; B.J. Schueler, 'De Awb en de bijzondere delen van het bestuursrecht', in: T. Barkhuysen e.a. (red.), Bestuursrecht harmoniseren: 15 jaar Awb, Den Haag: Boom Juridische uitgevers 2010, p. 173-191. 
Ook in de literatuur is het belang van uniformeren en systematiseren voor de toegankelijkheid geanalyseerd. ${ }^{19}$

Een wet waarin veelvoorkomende onderwerpen centraal worden geregeld, vergroot de kenbaarheid van de hoofdstructuren van het bestuursrecht. De jurist hoeft zich niet op elk deelterrein af te vragen tegen wat voor soort handelingen beroep openstaat, of eerst bezwaar moet worden gemaakt en hoe de procedure verloopt, of hij met een schadevergoedingsverzoek kan komen en welke betekenis toekomt aan beleidsregels. Ook de rechtsontwikkeling, waarin de algemene regels een rol spelen, is beter kenbaar dan wanneer het bestuursrecht zich uitsluitend op de deelterreinen zou ontwikkelen. Door het bestaan van een algemene wet, die het niveau van de deelterreinen overstijgt, kunnen de vragen over de interpretatie en toepassing ervan efficiënter worden beantwoord in jurisprudentie, commentaren en literatuur. ${ }^{20}$

Het is wel waar dat de Awb het rechtssysteem compliceert door een extra laag van regels en begrippen toe te voegen. Dat kan er bijvoorbeeld toe leiden dat er vragen rijzen over de juridische duiding van fenomenen die op deelterreinen tot ontwikkeling komen. Een voorbeeld is de vraag hoe een meldingensysteem zich verhoudt tot de begrippen en het systeem van rechtsbescherming van de Awb. ${ }^{21}$ In dit voorbeeld schept de Awb een complicatie doordat een atypisch fenomeen in het algemene systeem moeten worden ingepast, maar zodra dat werk is geklaard, wordt daarmee wel duidelijkheid gecreëerd over hoe met het fenomeen op een rechtsstatelijk verantwoorde manier kan worden omgegaan. De Awb schept hier een complicatie die per saldo 'loont'. Dat is niet per se altijd het geval met door de Awb gecreëerde complicaties. Over het subsidierecht heeft Den Ouden geschreven dat de gelaagdheid de rechtszekerheid voor subsidieverleners en -ontvangers bedreigt. 22

Daarom moet de Awb zo worden ingevuld dat zij de relatie tussen de algemene regels en de bijzondere delen van het bestuursrecht niet te ingewikkeld maakt. Toen de Awb werd ingevoerd, was die relatie nog eenvoudig. De Awb introduceerde een uniform begrippenkader en een aantal uniforme procedures. In latere fasen zijn daar onderwerpen aan toegevoegd die de relatie compliceren. Daarbij kan men denken aan de regeling van de subsidies, ${ }^{23}$ de lex silencio positivo, de dwangsom bij niet-tijdig beslissen (in het bijzonder in relatie tot de Wet open-

19 S.E. Zijlstra, T.C. Borman, S.A.J. Munneke, F.J. van Ommeren, A.E. Schilder \& E. Steyger, Wetgeven. Handboek voor de centrale en decentrale overheid, Kluwer: Deventer 2012, p. 167-176.

20 J.E.M. Polak \& W. den Ouden, Harmonisatie van bestuursrecht. De verschuivende horizon van het algemeen bestuursrecht en het subsidierecht in Nederland (Preadvies voor de Vereniging voor de vergelijkende studie van het recht van België en Nederland), Deventer: Kluwer 2004, p. 18-19.

21 Zie daarover de conclusie van A-G Widdershoven van 14 november 2014, inmiddels door de grote kamer gevolgd in de uitspraak 201303069/1/A3.

22 W. den Ouden, 'Ieder voor zich en de Awb voor ons allen? Over de verhouding tussen algemeen en bijzonder subsidierecht', in: M. Lurks e.a. (red.), De grootste gemene deler. Opstellen aangeboden aan prof. mr. Th.G. Drupsteen, Deventer: Kluwer 2002, p. 213-222. Zie ook Polak \& Den Ouden 2004 (i.h.b. hoofdstuk 2 en 4).

23 Den Ouden 2002, p. 213-222; Polak \& Den Ouden 2004 (i.h.b. hoofdstuk 2 en 4). 
baarheid van bestuur (Wob) $)^{24}$ en de bestuurlijke geldschulden. Kortmann heeft kritiek geleverd op de relatie tussen de Awb en andere algemene wetten, zoals de Grondwet, de Gemeentewet en de Provinciewet, onder andere over de gebrekkige aansluiting van de regeling van delegatie en mandaat in de Awb op de systematiek van en de praktijk onder die andere wetten. ${ }^{25}$

De verbetering van de kenbaarheid en toegankelijkheid van het bestuursrecht kan een reden zijn om onderwerpen te regelen in de Awb. Maar de gelaagdheid die erdoor ontstaat, kan averechts werken doordat die complicerend is.

Er zijn ook andere manieren om het bestuursrecht te ontsluiten voor de gebruikers. Een goed voorbeeld daarvan is de Omgevingswet. Daarin worden tientallen wetten geïntegreerd. Dat levert natuurlijk een complex geheel op, maar de systematische samenhang die met deze wet wordt beoogd, zal de gebruiker helpen om zijn weg te vinden naar de op zijn geval toepasselijke regels. Dat gaat beter dan wanneer hij een aantal min of meer op elkaar afgestemde wetten moet opsporen en toepassen. Kenbaarheid en toegankelijkheid kunnen vaak beter op een deelterrein worden bevorderd door middel van integratie van wetgeving. ${ }^{26}$

\section{Voorspelbaarheid}

De uniforme regels voor de besluitvorming (hoofdstuk 3 en 4 Awb) en het uniforme procesrecht (hoofdstuk 6, 7 en 8) helpen de gebruikers het verloop van procedures beter te voorspellen dan wanneer op afzonderlijke deelterreinen van het bestuursrecht verschillende procedures zouden worden ontworpen. ${ }^{27}$ Moeilijker is het om onderdelen van de Awb aan te wijzen die bijdragen aan de voorspelbaarheid van de uitkomst van de bestuurlijke en de rechterlijke procedures. De Awb bepaalt heel weinig over de inhoud van besluiten.

Dit is een verschijnsel dat men bij andere algemene wetten ook kan waarnemen. Een voorbeeld daarvan is het ontwerp voor de Omgevingswet. Deze wet regelt vooral de instrumenten (zoals onder andere plannen, programma's en vergunningen) die de overheid ter beschikking staan, de systematische samenhang daartussen en de toedeling van bevoegdheden. Dat laatste is een belangrijk verschil met de Awb, die slechts sporadisch bevoegdheden tot het nemen van besluiten aan

24 B.J. Schueler, R. Ortlep, E. Scholtes e.a., Evaluatie van een drietal versnellingsinstrumenten uit de Awb, Oisterwijk: Wolf Legal Publishers 2013.

25 C.A.J.M. Kortmann, 'Wie van de drie: de algemene wet, de algemene wet of de bijzondere wet?', in: C.A.J.M. Kortmann, B.P. Vermeulen \& P.J.J. Zoontjens, De Awb en de bijzondere wetgeving: preadviezen (VAR-reeks 124), Den Haag: Boom Juridische uitgevers 2000, p. 7-43 (i.h.b. p. 39). Besproken door S.E. Zijlstra, 'De verhouding tussen de Awb en de bijzondere wet', NTB 2000, p. 94-98. Ook H.Ph.J.A.M. Hennekens, 'De Algemene wet bestuursrecht en de Gemeentewet', in: M. Lurks e.a. (red.), De grootste gemene deler. Opstellen aangeboden aan prof. mr. Th.G. Drupsteen, Deventer: Kluwer 2002, p. 181-190.

26 Zie over de manier waarop: J. van den Broek, Bundeling van omgevingsrecht, Deventer: Kluwer 2012.

27 M. Scheltema, 'De Awb en het bijzondere bestuursrecht', in: M. Lurks e.a. (red.), De grootste gemene deler. Opstellen aangeboden aan prof. mr. Th.G. Drupsteen, Deventer: Kluwer 2002, p. 19-27. 
bestuursorganen toekent. ${ }^{28}$ Maar bij het voorspellen van de inhoud van besluiten biedt de Omgevingswet, net als de Awb, zelf nauwelijks houvast. Dat houvast wordt evenwel veel groter als men de op de Omgevingswet te baseren algemene maatregelen van bestuur en ministeriële regelingen ter hand neemt, waarin zeer veel inhoudelijke regels voor de besluitvorming zijn opgenomen. Daarnaast zal men in veel gevallen ook de decentrale regels in omgevingsverordeningen en omgevingsplannen nodig hebben om de uitkomst van bestuurlijke en rechterlijke procedures enigszins betrouwbaar te kunnen voorspellen. Hoe meer men erin slaagt de wetgeving op de verschillende niveaus tot een consistent geheel te maken en dat systeem ook in stand te houden, des te beter zal de Omgevingswet houvast kunnen bieden.

De Awb heeft een wezenlijk andere plaats in de rechtsorde. Zij vormt niet de basis voor nadere inhoudelijke regelgeving. De interpretatie van open Awb-normen, zoals evenredigheid en zorgvuldig onderzoek, alsmede open begrippen, zoals 'besluit' en 'belanghebbende', komt rechtstreeks op de tafel van de rechter terecht. Daardoor bestaat het risico dat door de Awb de uitkomst van procedures soms minder voorspelbaar is dan wanneer alleen de regels van het bijzondere deelterrein zouden gelden. Dit komt door de abstractie van de Awb-normen, die onvermijdelijk is omdat zij op zeer uiteenlopende terreinen toepasbaar moeten zijn.

Met een wet als de Omgevingswet is het mogelijk om wetgeving te integreren en te harmoniseren op een veel inhoudelijker manier. Toch is het de bedoeling dat de Omgevingswet en de erop gebaseerde regelgeving veel oningevuld zullen laten, zodat de bestuurlijke afwegingsruimte wordt vergroot en de maatschappelijke actoren meer bewegingsruimte krijgen. Dit is vooral een gevolg van een politieke keuze achter de Omgevingswet. Maar er zit meer achter, want de oningevulde ruimte in de normstelling is ook een voorwaarde om tot integratie van wetgeving te kunnen komen. Met alleen concrete dwingende regels is het niet mogelijk om de maatregelen ter behartiging van ongelijksoortige belangen als milieu, natuur, ruimtelijke ordening, water, bouwen, monumentenzorg (en nog meer) op een verantwoorde manier op te nemen in geïntegreerde regels.

Harmonisatie en integratie gaan gepaard met abstracte normen en met afwegings- en afwijkingsruimte. Voorspelbaarheid is niet per se gediend met harmonisatie en integratie.

\section{Efficiënte wetgeving}

Aan de Awb lag ook de verwachting ten grondslag dat wetgevers baat hebben bij algemene regels van bestuursrecht:

28 Een voorbeeld waarin de Awb dat doet, is het toekomstige art. 4:126 Awb over nadeelcompensatie. Wellicht mag men art. 4:81 Awb als een ander voorbeeld beschouwen, waarin is bepaald dat een bestuursorgaan beleidsregels kan vaststellen met betrekking tot een aan hem toekomende bevoegdheid, maar dat kan men ook beschouwen als een bevoegdheid die is geïmpliceerd in een op een andere wet gebaseerde bevoegdheid. 


\begin{abstract}
'De in een algemene wet geregelde onderwerpen behoeven geen voorwerp van regeling meer te zijn voor de bijzondere wetgever. Binnen de ministeries kunnen daardoor werk en tijd worden bespaard, hetgeen evenzeer geldt voor het interdepartementale overleg: de onderlinge afstemming van regelingen is eenvoudiger naarmate meer bepalingen uniform zijn. Dit effect doet zich niet alleen voor op de ministeries, maar eveneens bij de vele andere organen die met wetgevende taken zijn belast. ${ }^{29}$
\end{abstract}

Is deze verwachting uitgekomen? In de praktijk stuiten wetgevingsambtenaren regelmatig op de uniformerende pretenties van de Awb. Zij willen dan iets regelen wat afwijkt van de Awb. Hoewel dat wel kan, wordt het op de departementen die verantwoordelijk zijn voor de Awb niet gewaardeerd. Dat de Awb wordt beschermd tegen de neiging om op deelterreinen eigen regels te ontwerpen, is op zich goed. Niet alleen voor de bestuurs- en rechtspraktijk, maar ook voor de wetgevingspraktijk.

Ook hiervan biedt de Omgevingswet een voorbeeld. Dit is een zeer complex wetgevingsproject, waarin tientallen wettelijke regelingen worden geïntegreerd. Zonder de Awb zou dit project nog veel moeilijker te realiseren zijn dan nu al het geval is. De systematiek van het bestuursrechtelijke instrumentarium (zoals algemene regels, beschikkingen en handhaving) en de waarborgen (zoals zorgvuldige besluitvorming en rechtsbescherming) zijn al met de Awb gegeven. In de te integreren wetten zijn daardoor al in belangrijke mate identieke basisbegrippen en rechtsfiguren gebruikt. Op hoofdlijnen kennen zij al dezelfde systematiek van besluitvormingsprocedures en rechtsbescherming. Dat faciliteert de integratie. De kans op inconsistenties is kleiner dan wanneer elke wet haar eigen bestuursrechtelijke geraamte had gehad. De Omgevingswet, in combinatie met de daaronder hangende regelgeving, zal onvermijdelijk een complex geheel te zien geven. Toch begint nu al zichtbaar te worden hoe deze wet de toegankelijkheid van de omgevingsrechtelijke wetgeving zal verbeteren. De structuur ervan is helder, voor een belangrijk deel opgehangen aan de verschillende bestuurlijke instrumenten (zoals beleidsvisies, algemene regels en vergunningen). Deze structuur is meteen te koppelen aan de rechtsfiguren en de regels over besluitvorming, handhaving, rechtsbescherming en aansprakelijkheid uit de Awb. Zo valt een complexe nieuwe wet meteen in een bruikbare bestuursrechtelijke context, waar de wetgever op het bijzondere deelterrein op kan bouwen. Als straks - de verwachting is in of na 2018 - de Omgevingswet in werking treedt, zal het vertrouwde kader van de Awb houvast geven aan de zeer vele juristen die tot de nieuwe wet willen doordringen. Bij de interpretatie en de toepassing van de nieuwe wet zullen de begrippen en procedures van de Awb een vertrouwd kader bieden.

Efficiëntie in de wetgeving is een reden om de Awb als bestuursrechtelijke basis voor andere wetten te blijven gebruiken. Dat bevordert niet alleen het wetgevingswerk zelf, maar ook de implementatie en de toepassing van een nieuwe wet in de praktijk. 


\section{Waarborg voor rechtsstatelijkheid}

Bij het maken van keuzes om onderwerpen al dan niet in de Awb te regelen is de functie van de Awb als rechtsstatelijke waarborg een belangrijke richtingwijzer. ${ }^{30}$ Ook voor de vraag in hoeverre een onderwerp moet worden uitgewerkt in Awbregels kan deze functie houvast bieden. Scheltema herformuleerde in zijn in de inleiding al aangehaalde lezing het doel van de Awb als volgt: "het bieden van een eigentijds bestuursrechtelijk kader voor effectief bestuur op basis van de waarden van de rechtsstaat'.

De Awb bevat belangrijke waarborgen voor behoorlijke besluitvorming en voor de rechtsbescherming. $\mathrm{Zij}$ regelt de uitoefening van bevoegdheden die het bestuur zijn toegekend bij andere wetten. Zo begrenst de Awb de macht die de overheid ontleent aan andere wetten. De bijzondere wetgever kan er wel van afwijken, maar in de motivering van die afwijking zal hij redenen moeten geven. ${ }^{31}$ Het is voor de bijzondere wetgever moeilijk om de waarborgen te ontduiken, want doordat zij zijn samengebracht in een toegankelijke algemene wet, wordt het onmiddellijk zichtbaar tijdens het wetgevingsproces. Dat is ook het geval bij lagere regelgeving en bij beleidsregels. De bijzondere wetgever en de bestuurlijke regelgevers hebben regelmatig de neiging om de overheid slagvaardige instrumenten voor sturing en handhaving aan te reiken. Daarbij wordt vaak minder gedacht aan de middelen die burgers nodig hebben om voor hun belangen en rechten op te komen. De algemene strekking van de Awb waarborgt dat deze middelen in beginsel steeds beschikbaar zijn en niet zomaar opzijgezet kunnen worden.

Als een bestuursorgaan in een beleidsregel bijvoorbeeld te hoge boetes in het vooruitzicht stelt, kan de rechter die toetsen aan de Awb. Men ziet dat deze toetsing ook steeds duidelijker vorm krijgt. ${ }^{32}$ Beleidsregels kunnen geen afbreuk doen aan de waarborg die is neergelegd in artikel 5:46 lid 2 Awb. Daarin is de algemene evenredigheidsnorm uitgewerkt voor de boete: het bestuursorgaan moet de boete afstemmen op de ernst van de overtreding en de mate waarin deze aan de overtreder kan worden verweten, rekening houdend met de omstandigheden waaronder de overtreding is gepleegd. Een waarborg tegen onevenredig hoge boetes bevat de Awb zelfs voor gevallen waarin de hoogte van een boete exact is vastgesteld bij wettelijk voorschrift. Dan legt het bestuursorgaan, in afwijking van het wettelijk voorschrift, een lagere boete op 'indien de overtreder aannemelijk maakt dat de vastgestelde bestuurlijke boete wegens bijzondere omstandigheden te hoog is' (art. 5:46 lid 3 Awb). Het oordeel dat de boete omlaag moet, impliceert niet dat het wettelijk voorschrift in het algemeen een te hoge boete voorschrijft, maar wel dat de hoogte van de boete in het concrete geval niet evenredig is. Artikel 5:46 Awb is dus een voorbeeld van een bepaling die een waarborg biedt tegen de gevol-

30 Schueler 2010, p. 173-191 (par. 3).

31 Zijlstra e.a. 2012, p. 174.

32 Daarover C.L.G.F.H. Albers, M.L. van Emmerik, C.M. Saris \& F.J.P.M. Haas, Boetes en andere bestraffende sancties: een nieuw perspectief? (VAR-reeks 152), Den Haag: Boom Juridische uitgevers 2014. 
gen van disproportioneel optreden van bestuursorganen, lagere wetgevers en de formele wetgever.

Anderzijds helpt de Awb de wetgevers die juist willen weten dat zij de waarborgen van de rechtsstaat respecteren, want voor zover die waarborgen zijn neergelegd in de Awb, gelden zij indien er niet uitdrukkelijk van wordt afgeweken.

Het belang van de waarborgfunctie wordt in het huidige tijdsgewricht groter dan voorheen. Door decentralisatie en delegatie verschuift de inhoudelijke normstelling naar lagere regelgevers. Tegelijk zoekt de wetgever naar methoden voor dejuridisering van de besluitvorming en vergroting van de bestuurlijke afwegingsruimte. Dit leidt tot nieuwe vormen van interactie tussen overheid en burgers en dat vraagt soms om nieuwe waarborgen voor 'effectief bestuur op basis van de waarden van de rechtsstaat'.

Een voorbeeld bieden de decentralisatie in het sociaal domein, de overheveling van zorgtaken naar de gemeenten en de Wet maatschappelijke ondersteuning (Wmo), gepaard gaande met meer discretionariteit in individuele gevallen. Deze ontwikkeling creëert gedeeltelijk gedeformaliseerde contacten tussen burgers, overheid en private instellingen. Als er geschillen ontstaan, is het gangbare Awbmodel van bezwaar en beroep tegen een besluit minder geschikt geworden, omdat geschillen vaak betrekking hebben op meer dan alleen het besluit. De deformalisering is samengegaan met het streven om juridische procedures van rechtsbescherming te vermijden. Dit vraagt om een nieuwe kijk op de omgang met geschillen, een aanpak die afwijkt van wat gangbaar was. Bij deze ontwikkeling rijst de vraag of de bijzondere wetgever zich voldoende heeft gerealiseerd wat het belang is van een goed functionerend kader voor geschilbeslechting. ${ }^{33}$ Omdat het besluitmodel daar in deze context niet geschikt voor is, wordt nu nagedacht over een in de Awb te regelen verzoekschriftprocedure voor het sociaal domein onder het motto 'van gefragmenteerde naar integrale geschilbeslechting. ${ }^{34}$ In het 'spel' tussen de bijzondere wet en de Awb kan de laatste ook door nieuwe voorzieningen te treffen haar rol als waarborg voor rechtsstatelijkheid vervullen. Dat zou in dit geval leiden tot differentiatie van geschilbeslechtingsprocedures in de Awb. Dit voorbeeld laat zien dat de Awb niet 'bijna af' is. Veranderingen in wetgeving, bestuur, rechtspraak en samenleving vragen om veranderende waarborgen uit een oogpunt van rechtsstatelijkheid. De Awb is geen statische maar een dynamische waarborg, die op het juiste moment moet worden geactualiseerd. Zo houdt de wetgever zichzelf bij de les.

De waarborgfunctie van de Awb verdient ook de aandacht in de relatie tussen rechter enerzijds en bestuur en wetgever anderzijds. In de huidige situatie zijn er

33 E. Klein Egelink \& I. Lunenburg, 'Biedt de Wmo 2015 voldoende rechtsbescherming?', JBplus 2015, p. 42-70. Zie ook G. Vonk, 'Lokale verzorgingsstaat. Nieuwe uitdagingen voor de sociale rechtsstaat', NJB 2012, afl. 38, p. 2686-2693.

34 J.P. Roelfsema \& K.J. de Graaf, 'Decentralisaties in het sociaal domein. Verslag van een studiemiddag van de VAR, Vereniging voor bestuursrecht, gehouden op 9 oktober 2015', verschijnt in NTB 2015, afl. 10. Dit bouwt voort op de preadviezen van F.J. van Ommeren, P.J. Huisman, G.A. van der Veen \& K.J. de Graaf, Het besluit voorbij (VAR-reeks 150), Den Haag: Boom Juridische uitgevers 2013. 
voor het wetgevend-bestuurlijke machtsblok te veel mogelijkheden om de invloed van de rechter te verzwakken. Een van de mogelijkheden wordt geboden door het volgende mechanisme, dat zich onder meer in het omgevingsrecht voltrekt. De formele wetgever laat de inhoudelijke normstelling aan lagere regelgeving over. Tegen die lagere regelgeving staat vaak alleen hoogdrempelige rechtsbescherming open bij de burgerlijke rechter en geen rechtstreeks beroep bij de bestuursrechter. Steeds meer worden vergunningstelsels vervangen door algemene regels. Daardoor wordt niet alleen de rechtsbescherming van burgers beperkt, maar ook hun invloed op de normstelling. Want participatie bij de totstandkoming van een vergunning is beduidend intensiever dan bij de totstandkoming van een algemene maatregel van bestuur of verordening. Omdat de Awb geen beroep openstelt tegen algemene regels, faciliteert zij in haar huidige vorm de beperking van de rechtsbescherming door de bijzondere wetgever. Want men kan moeilijk stellen dat het de bijzondere wetgever niet is toegestaan bepaalde onderwerpen bij algemeen verbindend voorschrift te regelen. En het is de Awb, niet de bijzondere wet, die daar de consequentie aan verbindt dat er geen beroep bij de bestuursrechter meer openstaat. Deze gang van zaken is niet in strijd met EU-recht of internationale verdragen als het Europees Verdrag tot bescherming van de rechten van de mens en de fundamentele vrijheden (EVRM) of het Verdrag van Aarhus, want de burgerlijke rechter is ook een rechter als bedoeld in die bovennationale rechtsstelsels. We moeten het, als het om waarborgen gaat, hier dus hebben van de Awb.

Door het beschreven mechanisme wordt de normstelling 'verbestuurlijkt' en wordt tegelijk de rechterlijke invloed verzwakt. ${ }^{35}$ In dit mechanisme trekt het bestuur de macht naar zich toe, wordt de rechter op afstand gezet en laat de volksvertegenwoordiging dit gebeuren. Met het oog op de waarborgfunctie van de Awb moet opnieuw worden nagedacht over de wenselijkheid van het huidige artikel 8:3 lid 1 Awb, waarin algemene regels van beroep worden uitgesloten. Wel moet worden gezegd dat de regering het belang hiervan in het geval van de Omgevingswet gedeeltelijk onder ogen heeft gezien. Tegen de gemeentelijke regels van het omgevingsplan zal beroep op de bestuursrechter openstaan.

\section{Conclusie}

Wat zijn de belangrijkste redenen om algemene regels op te nemen in de Awb in plaats van een regeling te maken voor een deelterrein? In deze bijdrage zijn de meest voor de hand liggende redenen besproken vanuit vijf invalshoeken: rechtseenheid, kenbaarheid, voorspelbaarheid, efficiëntie in de wetgeving en borging van rechtsstatelijkheid.

Dit leidt mij naar de bevinding dat elk van deze invalshoeken belangrijk is, maar dat in het huidige tijdsgewricht vooral het belang van de efficiency in de wetgeving (par. 5) en dat van de borging van rechtsstatelijkheid (par. 6) groot zijn. Dat heeft te maken met twee ontwikkelingen.

35 Over 'verbestuurlijking' van de politiek: H.D. Tjeenk Willink, 'De rechterlijke functie in de veranderde democratische rechtsstaat', NJB 2014, afl. 1, p. 12. 
De eerste ontwikkeling komt erop neer dat het bestuur en de wetgevers in onderlinge samenwerking de slagkracht van het bestuur proberen te vergroten. De bijzondere wetgever en de bestuurlijke regelgevers hebben de neiging om de bestuursorganen slagvaardige instrumenten voor sturing en handhaving aan te reiken. Daarbij wordt vaak minder gedacht aan de middelen die burgers nodig hebben om voor hun belangen en rechten op te kunnen komen. De Awb waarborgt dat deze middelen in beginsel steeds beschikbaar zijn en niet zomaar opzijgezet kunnen worden. En de Awb faciliteert het inbouwen van deze middelen in nieuwe wetgeving, doordat zij een beproefd systeem biedt dat (soms met lichte aanpassingen) steeds als basis kan dienen voor een nieuwe bijzondere wet.

De tweede ontwikkeling heeft te maken met grootschalige verschuivingen in de wettelijke systemen, waardoor de normstelling in het publieke domein 'verbestuurlijkt', de rechter op afstand wordt gezet en de wetgever de inhoudelijke regelgeving naar het bestuur doorschuift. De volksvertegenwoordiging werkt daaraan mee of treedt er althans niet tegen op. Dit werpt een nieuw licht op de waarborgfunctie van de Awb, niet alleen op het belang van het behoud daarvan, maar ook op de noodzaak deze wet op het juiste moment aan te passen aan de eisen van de tijd. 